\title{
Las formas de la religión en la sociedad moderna
}

\author{
Celso Sánchez Capdequí \\ Universidad Pública de N avarra. D epartamento de Sociología
}

\section{Resumen}

El presente artículo expone las claves que explican el lugar que ocupa la experiencia religiosa en nuestra sociedad. Analiza su nueva posición a la luz de los intensos procesos de secularización, que, en un principio, vaticinaban su desaparición. La tesis que aquí se defiende es que la religión es inherente a toda vida humana y que, por tanto, su rostro puede cambiar adquiriendo tonos más o menos seculares.

Palabras clave: religión, secularización, sagrado, símbolo.

\section{Abstract. The forms of religi on in the modern soci ety}

This article analyzes the explaining aspects of the place of religious experience in our societies. It accounts for it in the light of the secularization processes that foretold its disapparence. The thesis defended here is that religion is something inherent to all human beings, and that therefore its face may change taking on more or less secular aspects.

Key words: religion, secularization, sacred, symbol.

Con el advenimiento de la sociedad moderna muchos han sido los sociólogos y, por extensión, los teóricos sociales que han subrayado el fin de la religión como manera de explicarse el mundo y de encontrar sentido a la existencia humana. El proceso de desencantamiento del mundo 1 iniciado, según Weber, «con las antiguas profecías judías y que, apoyado en el pensamiento científico heleno, rechazó como superstición y sacrilegio la busca de todo medio mági co para la salvación»², culmina con la génesis de una sociedad moderna en la que la religión pierde el centro trascendente legitimador que ocupaba en las socie-

2. Weber, M. (1992). Ensayos sobre sociología dela religión I. M adrid, p. 99. 
dades premodernas y se desplaza hacia la periferia como un discurso más entre otros. Frente a la cosmovisión centrada de las sociedades premodernas fundadas sobre el privilegio de la trascendencia religiosa ( $M$ ana, Wakan, $O$ renda, Isis, Buda, Jesucristo, etc.) y sobre su potencial de cohesionar y legitimar la unidad de lo social, en las sociedades modernas desaparece la tutela religiosa de lo social a la vez que se fragmenta la cosmovisión centrada en una suerte de plural ismo de discursos (economía, política, religión, etc.) 3 inmersos en un marco secular y todos ellos portadores de lógicas y de simbólicas autónomas e irreductibles entre sí.

Este proceso de secularización y su efecto concomitante de desencantamiento del mundo han supuesto para la comunidad sociológica de nuestros días un foco de debate permanente en el que, por lo general, ha primado la tesis de la paulatina pérdida de influencia de la experiencia religiosa en la sociedad moderna. En concreto, uno de los fundadores de la ciencia sociológica, A. Comte, afirma que la percepción religiosa del mundo corresponde a un momento evolutivo de la humanidad ya superado y en la actualidad sustituido por la comprensión científica de la vida social ${ }^{4}$.

Esta tesis defendida por Comte y otros, se ha institucionalizado como moneda común del pensamiento occidental bajo la constatación de una socie dad moderna que, dispuesta sobre un imaginario psicosocial en el que el progreso es significación social privilegiada, no ha parado de intensificar sus procesos de evolución, cambio y mejora materiales. El avance en lo científico-técnico ha supuesto la expansión de los criterios funcionales como esquemas de representación de la sociedad moderna y, a su vez, la aparición de sus efectos perversos, la colonización del mundo-de-la-vida por el sistema en los

3. Consultar el texto de M ax W EBer El político y el científico. M adrid, 1986, p. $218 \mathrm{~s}$.

4. En la sociología clásica también el mismo $M$ arx arremete contra la religión al definirla como ideología y falsa conciencia, como forma sustitutiva de felicidad en el insatisfactorio marco social moderno, cuya auténtica verdad se encuentra en la lucha de clases y en las relaciones de propiedad. En la sociología contemporánea conviene recordar la tesis que defiende Niklas Luhmann. La posición de este sociólogo alemán respecto a lo religioso en toda sociedad se inscribe en un esquema de base de marcado carácter evolutivo, si bien éste no responde en sus procesos de despliegue a momentos y tramos predeterminados sino siempre contingentes. Lo religioso haría alusión a la primi genia determinación de la indeterminación ontológica (Funktion der Religion, Frankfurt am M ain, 1990, p. 200), a la explicación primordial que las sociedades no diferenciadas efectuán de las contingencias (naturales, climatológicas, geológicas, la muerte, etc.) que amenazan con quebrantar su orden instituido. En definitiva, las construcciones religiosas ( $M$ ana, O renda, Isis, Yahve, Jesucristo, etc.) han aparecido a los ojos de la humanidad primigenia como instancias desparadojizadoras, como posibilidades imaginarias y míticas anuladoras de la complejidad y paradoja originarias. Sin embargo, el proceso de diferenciación funcional ha modelado un marco institucional, el moderno, que ha hecho de la simbólica religiosa una simbólica más y periférica, y ha concedido preeminencia a la representación funcional basada en esquemas de predicción y planificación técnica. La presencia de lo religioso poco puede aportar en referencia a un mundo mucho más complejo que los anteriores en el tiempo y, por ende, más necesitado de un soporte técnico-administrativo portador de un nivel de abstracción y complejidad igual o mayor que el que posee el entorno exterior. 
términos de $\mathrm{H}$ abermas. Fruto de esto ha sido la desaparición de la huella de lo sagrado en la modernidad y el silencio con la que ésta responde a las preguntas existencial es recurrentes (la muerte, la libertad, el amor, etc.) para toda forma de vida5.

Precisamente el ideal de progreso que atraviesa el magma de significaciones sobre el que se edifica la percepción moderna de lo real ha facilitado que ésta incline su interés hacia el potencial liberador del «conocimiento humano» centrado y plasmado en una fe ilimitada en el saber científico. Lo que antes era estabilidad, oscuridad y tradición bajo el predominio de la religión, ahora deviene dinamismo, desarrollo y autonomía de un saber que en su permanente progreso y avance facilita la mejora (material) de la vida humana.

D e esta suerte, el sesgo de la sociedad moderna «no apunta ya hacia el sentido sino hacia la verdad. La aventura moderna es fundamental mente epistemológica; enuncia las condiciones de la certeza, ausculta los límites de la razón, estudia las variables formas de adecuación entre el hecho y la palabra, entre el sujeto y el objeto, entre el pensamiento y el mundo»6. Sin embargo, el inextinguible potencial de sentido que anida en la vida religiosa parece desafiar a los pronósticos sociológicos que certificaban su defunción definitiva. Con la llegada de la modernidad, tiempo de la gran ocultación ${ }^{7}$ según expresión de Eugenio Trias, la religión redujo su sofocante omnipresencia social, pero no desapareció definitivamente, ya que sólo ella puede responder a preguntas existenciales que regresan en la vida humana de cualquier tiempo y sociedad. No así la ciencia, ya que, en palabras de W ittgenstein, «aun cuando todas las posibles cuestiones científicas hayan recibido respuesta, nuestros problemas más vitales todavía no se han rozado en lo más mínimo». La condición irreductible de lo religioso en cual quiera de las sociedades humanas no habla en favor de una recuperación de lo sagrado como eje nuclear de la estructuración social, sino como ámbito específico de la vida social en el que no rigen la verdad y su método de conocimi ento (explicativo de las cosas), sino el sentido (implicativo con el todo), en concreto, «un sentido que no quiere morir»?.

En definitiva, el ideal del progreso científico inundó de tal modo el imaginario de la sociedad moderna que acabó por ocultar las necesidades axiológicas de las que participa toda vida humana. É stas se quedaron sin respuesta. Por ello, ciertos teóricos sociales se brindaron para revisar los presupuestos téricos de las sociedades modernas y abrirlos a la dimensión no epistemológica pero sí axiológica de la religión. Sin embargo, la perspectiva de análisis más

5. BeLL, D. (1990). «T he Return of the Sacred». En The Winding Passage. N ueva York: p. 333.

6. Lanceros, P. (1994). «Al filo de un aforismo». En Ortiz-O sés, A.; Lanceros, P. (ed.). Arquetipos y símbol os col ectivos. Barcelona, p. 416.

7. TRIAS, E. (1997). Pensar la religión. Barcelona, p. 27.

8. Wittgen Stein, L. (1989). Tractatus Logico-Philosophicus. M adrid, p. 181.

9. FerrarotTI, F. (1994). «El destino de la razón y las paradojas de lo sagrado». En D iazSalazAR, R.; Giner, S.; Velasco, F. (ed.). Formas modernas de religión. M adrid, p. 302. 
frecuente conllevaba ciertos reduccionismos de la simbólica religiosa10. Así, por ejemplo, el sociólogo francés E. D urkheim, en su trabajo Las formas ele mentales de la vida religi osa, lanza una tesis hoy prácticamente incuestionable: la religión es constitutiva de la vida humana e irreductible a cualquier otro universo simbólico, como el científico, el económico, etc. Por ello, nada puede hacer pensar que su existencia en la historia de las sociedades humanas sea transitoria. Como afirma D urkheim, «hay, pues, al go eterno en la religión que está destinado a sobrevivir a todos los símbolos particulares con los que se ha recubierto sucesivamente el pensamiento religioso. N o puede haber sociedad que no sienta la necesidad de conservar y reafirmar, a intervalos regulares, los sentimientos e ideas colectivos que le proporcionan su unidad y personalidad. Pues bien, no se puede conseguir esta reconstrucción moral más que por medio de reuniones, asambleas, congregaciones en las que los individuos, estrechamente unidos, reafirmen en común sus comunes sentimientos; de ahí la existencia de ceremonias que, por su objeto, por los resultados a que llegan, por los procedimientos que emplean, no difieren en naturaleza de las ceremonias propiamente religiosas.

Los antiguos dioses envejecen o mueren, y todavía no han nacido otros. Pero esta situación de incertidumbre y confusa agitación no puede durar eternamente. Llegará un día en que nuestras sociedades volverán a conocer horas de efervescencia creadora en cuyo curso surgirán nuevos ideales, aparecerán nuevas formulaciones que servirán, durante al gún tiempo, de guía a la huma nidad. N o hay ningún evangelio que sea inmortal y no existe razón al guna para creer que la humanidad sea ya incapaz de concebir uno nuevo»11. Como afirma Joan Estruch al hilo de este párrafo de D urkheim, todo desencantamiento del mundo supone e implica a la vez la emergencia de nuevas formas de reencantamiento. En definitiva, significa que «la religión no desaparece sino que se transforma. Q ue la nuestra es una época de crisis religiosa: pero crisis en el sentido de que está produciéndose una metamorfosis de la religión, y no en el sentido de su abolición»12.

Se trata, por tanto, de reconocer la multiplicidad de rostros que puede adoptar la experiencia religiosa en cualquier tipo de sociedad, la variedad de formatos, doctrinas, confesiones, dogmas, símbolos y ritos en que puede tomar cuerpo lo sagrado. Sin embargo, el propio tratamiento que D urkheim hace de lo religioso es reduccionista 13 . Aunque entiende los aspectos religiosos adheridos a toda vida humana desde el punto de vista de su permanencia y de su recon-

10. Tal vez de las aportaciones más destacadas a este respecto sean la de M arx cuando elimina de la religión toda especificidad y la reduce a superestructura que edulcora espiritualmente los auténticos problemas estructurales de la sociedad moderna, en concreto, la contradicción capital-trabajo.

11. DURKHEIM, E. (1992). Las formas el ementales de la vida religi osa. M adrid, p. 398

12. EstRUCH , J. (1994). «El mito de la secularización». Formas modernas de religión. M adrid, p. 279.

13. M ARD ONES, J.M . (1994). Para comprender las nuevas formas de la religión. Estella (N avarra), p. 16. 
figuración y transformación temporal e histórico-social, reduce su realidad a la de mera hipóstasis de la conciencia colectiva y del orden social ya instituido como tal orden. La versión durkheimiana de la religión en la que ésta es reproducción hipostasiada del orden social, se constata en la manera de entender el símbolo central o tótem de toda sociedad, el cual «no puede ser más que el clan mismo, pero hipostasiado y concebido por la imaginación en la forma de las especies sensibles del animal o vegetal utilizados como tótem»14.

Sobre este planteamiento en que se privilegian las instancias de conciencia colectiva y de orden en lo social, en cuanto condiciones de posibilidad desde las que se hipostasia la experiencia religiosa como algo segundo y reflejo, cabe entender mejor la definición durkheimiana de la religión que, al eliminar los caracters autónomos e irreductibles de la misma, destaca sus aspectos más cercanos a lo instituido, como son los rasgos normativos, doctrinales, prescriptivos e institucionales, es decir, confesionales, olvidando sus instancias específicas (lo sagrado y lo numinoso) en el marco de una visión funcionalista de la religión en la que predomina su poder de regulación y de control de la acción social. D e esta manera, D urkheim entiende la religión como «un sistema solidario de creencias y de prácticas relativas a las cosas sagradas, es decir, separadas, interdictas, creencias y prácticas que unen en una misma comunidad moral, Ilamada I glesia, a todos aquellos que se adhieren a ellas»15.

Tras esta sucinta exposición de la problemática religiosa en la modernidad y de la posición de uno de los paradigmas sociológicos más influyentes al respecto, como el de D urkheim, se trata de desplazarse hasta la esfera nuclear, específica e irreductible de la religiosidad, en concreto, a lo sagrado como elemento permanente (sincrónico) que, por su carga de ilusi ón16 (Freud) constitutiva y regeneradora, hace impensable la desaparición de lo religioso de la vida humana.

Sobre esta base teórica, paso a dar cuenta de uno de los paradigmas de pensamiento, como el del fenomenólogo dela religión Rudolf 0 tto, que se interesa por la esencia del fenómeno religioso sin reduccionismos de ningún tipo y que incide en la idea defendida por B ell de que «la religión hunde sus raíces en lo existencial»17, eliminando con ello la escisión entre lo vivido (sagrado) y lo pensado (profano) ${ }^{18}$.

El fenomenólogo alemán Rudolf 0 tto ha sido uno de los estudiosos de la problemática religiosa que más afán ha puesto en la explicitación teórica de sus notas estructurales, específicas y, por ende, irreductibles a los criterios que

14. D URKHEIM , E. (1992). Las formas elementales de la vida religiosa. M adrid, p. 194.

15. DURKHEIM, E. Ibídem, p. 42.

16. Freud, S. (1993). Psicología delas masas. M adrid, p. 168-169.

17. BELL, D. O p. cit., p. 351.

18. Ferraroti, F. Op. cit., p. 303. 
rigen otros despliegues simbólicos, como el científico, el político, etc., por ejemplo19.

Sin descuidar los aspectos institucionales y confesionales de la religión, 0 tto va a centrar su exploración en la dimensión irracional y paradójica que subyace a toda escenificación religiosa del grupo social, sea éste cualquiera que sea. En concreto, fija su atención en lo que denomina primeramente lo sagrado, lo santo (das $\mathrm{H}$ eilige), pero que, por su frecuente comprensión en clave moral, reformula como lo numinoso. Con él refiere al nervio de la religión, «a la emoción misma de lo divino» 20 experimentada por el grupo social, a la vivencia de trascendencia y arrobami ento que se expresa colectivamente en un tótem o símbolo central, así como en un conjunto de actos rituales a cuyo través el grupo recuerda periódicamente su tótem o símbolo central y, además, la filiación sagrada de la vida social.

Las pautas de análisis de 0 tto trascienden la dimensión puramente racional, moral y confesional de la religión. Reculan hasta la sima sentimental donde la vivencia intersubjetiva es interpelada por lo totalmente otro, por la coincidentia oppositorum que hace de la forma simbólica de la religión algo no analizable con conceptos puramente racionales guiados por el principio de identidad 0 determinación (Bestimmheit) en los términos de Castoriadis.

Aquí el análisis de lo religioso transita terrenos más confusos y quebradizos que a los que habitual mente acostumbra cuando se entiende a la religión desde lo racional, desde su condición de dogma y confesión, es decir, desde sus manifestaciones morales y normativas. Las aportaciones de Rudolf $\mathrm{O}$ tto al problema suponen el traslado del mismo a una dimensión experiencial, anímica y emotiva, en la que la voluntad del colectivo se ve avasallada por fuerzas, poderes y potencias que «dentro de su mundo, la experiencia los ha presentado suficientemente poderosos, peligrosos y útiles para tomarlos en respetuosa consideración, o lo suficientemente grandes, bellos y razonables para adorarlos piadosamente y amarlosi»1.

D e esta suerte, Io religioso, en cualquiera de las formas sociales en que se expresa, es, junto a su dimensión institucional, pura emoción, sentimiento eilusión en los términos de Freud. Ya C.G. Jung, desde el terreno de la psicología de la cultura, afirma que «con el término religión no me refiero a un credo. Es cierto, empero, que toda confesión, por un lado, se funda originariamente en la experiencia de lo numinoso y, por otro, en la pistis, en la fidelidad (lealtad), la fe y la confianza ante una señalada experiencia de efecto numinoso y el cambio de conciencia que resulta de ésta»22.

Va quedando claro, por tanto, que la perspectiva que Rudolf 0 tto emplea en el análisis de la religión, antes que al poder moral y normativo inherente a

19. Esta tesis la defiende el filósofo neokantiano Ernst C assirer en su voluminosa obra Filosofía delas formas simbólicas (M éxico, 1972), en concreto, en su segundo tomo.

20. Отто, R. (1922). Lo santo. M adrid, p. 222.

21. Jung, C.G. (1987). Psicología y religión. Barcelona, p. 23.

22. Jung, C.G., Ibídem, p. 24. 
cual quier credo religioso, refiere a la vivencia colectiva de lo sagrado, trascendente y numinoso desprovista de criterios racionales y morales. D e esta suerte, Ferraroti afirma que «el homo religiosus no es el hombre de I glesia. Él es el hombre de la escucha y de la espera. D emuestra una capacidad casi infinita de espera de manifestación del ser «23. En clave sociológica, ya $M$ affesoli ha recordado que antes de su estructuración racional como cuerpo ordenado, la sociedad se instituye desde lo que él denomina «la socialidad de predominio empático» 24 y que alude al conjunto de «sentimientos vividos en común» 25 desde los cuales se funda todo ethos social. Sobre este entusiasmo de fondo la sociedad es capaz de hipostasiar su sentido latente y, por ende, de crear imágenes y significaciones colectivas, tanto de cariz religioso (Buda, J esucristo, etc.) como laico (revolución, progreso, democracia, etc.). El mismo D urkheim sostiene que esa corriente de emoción religiosa de la que se sirve la sociedad «para crear dioses no fue en ningún momento más perceptible que durante los primeros años de la revolución francesa. En aquel momento, en efecto, bajo la influencia del entusiasmo general, cosas puramente laicas fueron transformadas, por parte de la opinión pública, en cosas sagradas: así la Patria, la Libertad, la Razón. H ubo la tendencia a que por sí misma se erigiera una religión con sus dogmas, sus símbolos, sus altares y sus festividades. El culto de la Razón y del Ser Supremo intentó aportar una especie de satisfacción oficial a esas aspiraciones espontáneass 26 .

A continuación, paso a efectuar una descripción de las notas características y específicas de lo numinoso (lo sagrado, lo santo) como núcleo básico del elemento religioso, siempre sobre la base del paradigma teórico propuesto por Rudolf $\mathrm{O}$ tto, que tiene en cuenta la vivencia profunda y religadora del grupo social:

1. Lo numinoso dispone de una naturaleza dinámica, móvil y en permanente tránsito. Refiere más a una energía que a un ser acabado formalmente, a la coincidentia oppositorum que al pensamiento identitario. 0 tto lo caracteriza con términos como «pasión», «vida», «voluntad», «fuerza», «agitación», «impulso», etc. En sus estudios sobre las tribus australianas D urkheim constata como éstas incorporan en sus explicaciones mitológicas del mundo la dimensión realizadora y revitalizadora de lo numinoso sobre la que se yerguen todas las manifestaciones de vida (humana, animal, vegetal), a la vez que las pone en un contacto coparticipativo (Levi-Bruhl). Por ello, los iroqueses emplean el término O renda; Ios sioux, Wakan; los melanesios, M ana. Esta energía «va y viene a lo largo del mundo, y las cosas sagradas constituyen los puntos en que se posasx7. En definitiva, a la base de cual quier objeto de

23. Ferrarotti, F. O p. cit., p. 302.

24. M AfFesoli, M. (1990). El tiempo delas tribus. Barcelona, p. 37.

25. M AFFESOLI, M. Ibídem, p. 24.

26. DURKHEIM, E. (1992). O p. cit., p. 201.

27. DuRKheim, E. Ibídem, p. 188. 
adoración y culto social, fluye una corriente vital e impersonal que, cristalizada en un tótem (D urkheim), dimana unas resonancias y evocaciones que ligan a la sociedad con lo sacro y lo primordial, en definitiva, con lo divino. Sobre la natural eza energética de la experiencia religiosa afirma D urkheim que «lo que encontramos en el origen y la base del paradigma religioso, no son objetos o seres determinados y distintos que posean por sí mismos un carácter sagrado, sino poderes indefinidos, fuerzas anónimas, más o menos numerosas según las sociedades, a veces incluso unificadas, cuya impersonalidad es estrictamente comparable a la de las fuerzas físicas cuyas manifestaciones estudian las ciencia de la natural eza»28.

2. Por otra parte, lo numinoso refiere a un horizonte de sincronicidad, a un orden implicado (D. Bohm) en el que la vivencia significativa de lo sagrado por parte de la sociedad es contemporánea del eterno fluir de la energía numinosa ${ }^{29}$ en que consiste lo real y que, por ello, hace impensable la desaparición de la religión en la vida humana. El cáracter sincrónico de lo numinoso tiene en consideración su disposición eterna, constante e imperecedera, su movilidad permanente sobre cuyos pliegues/repliegues brota la experiencia religiosa del grupo y su inherente potencial de creación 30 . La sincronicidad fundamental del pensamiento religioso trae a colación la tesis de $D$ aniel Bell de que las interrogantes de ultimidad (muerte, amor, libertad, etc.) recurren inexorablemente en todo tiempo y lugar desde ese fondo ambivalentey numinoso que, por su carácter imperecedero, no deja de interpelar a cual quier sociedad, obligándola a generar certezas en torno a imágenes religiosas, símbolos y ritos.

3. Lo numinoso aparece en la vivencia religiosa como algo ambivalente y desprovisto de cualquier cariz exclusivamente bueno o malo. En otros términos, el juicio moral queda suspendido ante él. Rudolf 0 tto dice a este respecto que lo numinoso hace las veces, simultáneamente, de mysterium tremendum y de majestad tremenda. Por un lado, transmite a quien lo vivencia temor y pavor por su condición de lo absolutamente otro31, por su heterogeneidad 32 respecto de las categorías racionales del pensamiento humano

28. DURKheim, E. Ibídem, p. 188.

29. Véase el texto de D avid Boн M , La totalidad y el orden implicado (Barcelona, 1987, p. 212 s.), donde identifica la movilidad numinosa con el halomovimiento de que se constituye lo real (frente al carácter estático predominante en el ser de la ontología griega). Ya en el campo de la sociología hay teóricos que se atreven a suscribir la idea de ese fondo dinámico y sincrónico que subyace a toda cristalización social, por ejemplo, Castoriadis con el término magma, en el cual Joas, M affesoli, Balandier, etc. ven la posibilidad permanente de creación de impre visibles formas sociales.

30. Sobre el potencial creador de la ilusión que anima toda experiencia religiosa (Freud), afirma Unamuno que «a fe es, pues, si no potencia creativa, flor de la voluntad y su oficio crear. La fe crea, en cierto modo, su objeto. Y la fe en Dios consiste en crear a D ios» (El sentimiento trágico de la vida. M adrid, 1991, p. 184).

31. Oтto, R. (1992). O p. cit., p. 41.

32. Отто, R., Ibídem, p. 115. 
y por su ser paradójico constitutivo33. Este temor que dimana de lo numinoso se constata en la descripción colérica que de Yahvé aparece en el Antiguo Testamento. En concreto, muchos de sus pasajes evidencian que esta cólera divina no tiene nada que ver con propiedades morales. «Se inflama y desencadena misteriosamente "como una fuerza oscura de la naturaleza", según suele decirse, o como la electricidad acumulada, que descarga sobre quien se le aproxima. Es "incalculable" y "arbitrario"»34.

Al mismo tiempo, lo numinoso, por su prepotencia absoluta, aparece como la plenitud de realidad 35 , frente a la cual el yo/nosotros se percibe como una nada, como total mente dependiente de él. Se trata de la realidad suprema dadora de sentido, certidumbre y seguridad. Frente a lo numinoso, aparece aquel sentimiento de criatura que surge «al contraste de esa potencia superior como sentimiento de la propia sumersión, del anonadamiento, del ser tierra, ceniza, nada, y que constituye, por así decir, la materia prima numinosa para el sentimiento de la humildad religiosa»36. A su través, se constata una distancia insal vable entre el mundo de la inmediatez profana y de la razón lógica y el ámbito de lo sagrado (sólo aprehensible simbólicamente como se verá a continuación).

4. La coincidentia oppositorum inherente al ser fluente y vivo de lo numinoso hace impensable su captación en términos racionales, a través del pensamiento dicotómico e identitario. Por lo mismo, el acercamiento del hombre a su realidad se lleva a cabo mediante la que G ilbert D urand denomina una conciencia indirecta 37 que, frente a la total adecuación entre significante y significado de la conciencia directa (científica, por ejemplo), refiere a un ámbito de trascendencia (imágenes religiosas cargadas de numen) donde existe una carga de resonancias semánticas que hace imposible fijar con precisión significantes con significados dejando espacio para la libre interpretación humana.

Se trata, por tanto, de una aprehensión simbólica de lo numinoso. A este respecto, conviene recordar la diferencia entre signo (predominante en la conciencia directa) y símbolo (privilegiado en la conciencia indirecta). El primero es tan sólo un medio destinado a economizar, remite, por tanto, «a un significado que puede estar presente o ser verificado ${ }^{38}$. D e esta manera, un signo se limita a prevenir la presencia del objeto que representa (por ejemplo, unas fórmulas científicas representan objetos del mundo objetivo). El símbolo, por el contrario, remite a algo inefable, a lo absolutamente otro (Rudolf $\mathrm{O}$ tto) inatra- 
pable racionalmente. En palabras de G ilbert D urand, el símbolo «es "confirmación" de un sentido a una libertad personal»39. En él no hay delimitaciones precisas de pares de significados y significantes y su potencial de evocación humana es inextinguible.

La trasposición de lo simbólico a lo social, como marco de concreción de lo numinoso vivido colectivamente, se lleva a cabo a través de lo que M ircea Eliade, entre otros, han denominado hierofanías 40 . Bajo este término, se incluyen a todas aquellas realidades pertenecientes al ámbito mundano de la existencia que determinado grupo social experimenta como reveladoras de órdenes trascendentes de real idad. Una piedra, un árbol, un canguro, una cruz pueden servir para presencializar las instancias ontológicas de la vida social, para manifestar las significaciones latentes que estructuran y animan una forma de vida. Por esto, todo tótem es un hierofanía, ya que para el colectivo su sola presencia remite a un horizonte de experiencia humana que excede los límites de lo mundano. En ella se concentra el sentido del grupo, la memoria ancestral y, por ende, los límites imaginarios de su identidad colectiva.

Tras la exposición de lo más específico e irreductible del numen (de lo sagrado) que hace posible toda experiencia religiosa, voy a proponer con Clifford $G$ eertz una definición de lo religioso en la que cohabitan lo institucional y lo instituyente, el orden en sus prescripciones y el numen-caos de la emotividad social, por tanto, lo histórico-confesional y lo sincrónico-vitalista. D e esta suerte, afirma G eertz que la religión para cualquier forma social refiere a «un sistema de símbolos que obra para establecer vigorosos, penetrantes y duraderos estados anímicos y motivaciones en los hombres formulando concepciones de orden general de la existencia y revistiendo estas concepciones con una aureola de efectividad tal que los estados anímicos y motivaciones parezcan de un realismo único» 41 .

En definitiva, lo religioso dispone de una dimensión objetiva e institucional, como la ratifica D urkheim con el manejo que hace del término I glesia, pero asimismo hace gala de un aspecto prerracional y vitalista en el que habita lo numinoso como «energía» 0 «corriente vital» $0 \mathrm{M}$ ana (Wakan, 0 renda, etc.), cuyo devenir sincrónico explica, tanto (1) el carácter imperecedero de lo religioso, como (2) su permanente reconfiguración y mutación temporal.

A continuación voy a intentar describir las formas que toma lo numinoso (lo sagrado) en la vida moderna. Previamente me ocuparé de los cambios estructurales que ha introducido la experiencia moderna del mundo y que han influido en la específica forma que tiene la actual sociedad de vivir la religión. 
1. H a sido Thomas Luckmann el que ha incidido en una expresión que pone bien a las claras el papel de la religión en la modernidad. Esta expresión, que no es otra que la de religión invisible, subraya la eliminación del discurso religioso como núcleo básico legitimador de la vida social y la aparición de la experiencia religiosa vivida individualmente sin el carácter asambleario del que hablaba D urkheim. Según su punto de vista, la estructura cosmovisional e institucional de esta sociedad se caracteriza por un pluralismo simbólico que, en virtud del profundo proceso de secularización42 al que ha asistido los últimos siglos, hace de la religión un discurso más entre otros. La sociedad moderna, en expresión de H abermas, descentrada, ya no dispone de una imagen del mundo cerrada, legitimada por la tradición y estática en su estructura y en sus creencias, sino que hace gala de diferentes modos de decir-representar la realidad (economía, política, ciencia, etc.) que, ubicados en la experiencia mundano-secular, disponen de lógicas y resortes simbólicos irreductibles entre sí. Se trata de una sociedad sin la tutela religiosa omnipresente en las sociedades premodernas.

Para D urkheim los procesos de diferenciación funcional de la sociedad moderna han supuesto la aparición de nexos de interacción social de carácter profesional y económico en detrimento de los consanguíneos o filiales. Aquellos suelen ser por breves instantes, crean lazos externos y no posibilitan ni la interpenetración ni adhesión de una conciencia con otra que con tanta frecuencia ocurre bajo una atmósfera si gnificativa y común 43 . En con-

42. M ichael H ill, en su trabajo Sociología de la religión (M adrid, 1988, p. 287 s.), desarrolla diferentes significados con los que se ha entendido el concepto de secularización en el horizonte sociológico: 1) D ecadencia de la religión: en este caso se trata de constatar la pérdida de prestigio e influencia de los dogmas religiosos para coordinar y unir axiológicamente a la sociedad moderna. D esde esta perspectiva se puede hablar de una sociedad irreligiosa como punto final del citado proceso; 2) Tránsito del rechazo de este mundo a su aceptación: al go que se objetiva en la aparición de una ética pragmática en que las necesidades actuales pasan a ser la fuente más importante de las motivaciones (frente a la tradición ética ligada a una vida futura); 3) Separación entre la religión y la sociedad: con esta interpretación se refiere a la pérdida de la religión del protagonismo legitimador de la sociedad en su conjunto. Consustancial con el proceso de diferenciación funcional, la religión pasa a ser una esfera de valor más en el seno de una vivencia mundanizada de lo real y se recluye en la esfera puramente privada, restringida a la esfera de quienes les interesa su «producto ofertado» (Berger); 4) Transposición de las creencias y actividades de un punto de vista sagrado a un punto de vista secular: I función integradora y omniexplicativa de la religión la llevan a cabo movimientos como el comunismo, nacionalismo, etc. A su vez, las identidades colectivas y las ideol ogías sirven como equival entes funcionales de la religión; 5) D esaparición de las imágenes sagradas del mundo; la incapacidad moderna para alzar la vista (Benjamin) recuerda a la expresión weberiana de desencantami ento del mundo (D ie Entzauberung der Welt) en el que se escinden la totalidad religiosa premoderna de naturaleza, sociedad y yo en universos legitimados procedimental mente, nunca por recursos a trascendencias preexistentes, y 6) Paso de una sociedad sagrada a una secular: aquélla dispone de unas estructuras fijas poco predispuestas al cambio frente a ésta, que, además de la novedad, admiten sin problemas a las influencias externas.

43. DuRKheIM, E. (1987). La división social del trabajo. M adrid, p. 241. 
creto, la semejanza de las conciencias existente en las sociedades nodiferenciadas se difumina simultáneamente con la emergencia de un intenso proceso de división social del trabajo que responde al volumen y a la densidad que las sociedades modernas adquieren en su desarrollo y, por ende, a la formación de estructuras sistémico-funcional es que satisfagan las necesidades materiales de la población. La aparición de nuevos modos de producción, el progreso técnico, el desplazamiento de la masa trabajadora, el desarraigo de la misma, son motivos suficientes con los que dar cuenta de la desaparición de una conciencia común que, según D urkheim, no da fuerza sino por ser legado de las generaciones anteriores ${ }^{44}$, algo que en la modernidad industrial ha perdido todo su influjo como esquema de legitimación social. En todo caso, la desaparición de una estructura simbólica común (Bell), se corresponde con la emergencia de una pluralidad de formas de vida que hacen imposible el privilegio de cualquiera de ellas.

2. Esta descripción del descentramiento cosmovisional de la sociedad moderna coincide con la aparición de la significación social «ndividuo». Sin una conciencia colectiva niveladora de las psiques individuales, el individuo se ve obligado destinalmente a recomponer la imagen del mundo sin otro criterio que su propia determinación carente de apoyos interpretativos externos. Éste es el acontecimiento más revolucionario de la sociedad moderna45. Los diferentes universos simbólicos se autonomizan con sus lógicas específicas, la realidad adquiere un cariz abierto en el sentido que ha de ser acabada por el individuo sin apoyo nómico-normativo fijo, estable y exterior que en sociedades premodernas era proporcionado por la institución I glesia en connivencia con el apoyo que le prestaba el Estado a la hora de «oficializar» públicamente una manera de ver-creer social. La separación entre política (Estado) y religión (I glesia), o la también llamada despolitización de la religión, va de la mano de otros rasgos que caracterizan la vivencia y el rito religiosos en la modernidad. Roberth Bellah destaca los siguientes: eliminación de cualquier monopolio doctrinal, el no confinamiento (o por lo menos no necesariamente) de la acción religiosa a la I glesia y a su carácter asambleario descrito por D urkheim y, especialmente, la privatización de la experiencia de lo sagrado, todo lo cual le lleva a T. Luckmann a hablar de religión invisible. La desregulación institucional de la simbólica de las grandes trascendencias convierte al individuo en sujeto activo de su reconstrucción axiológica, al margen de monopolio doctrinal alguno.

En definitiva, junto al ocultamiento de cualquier estándar de ortodoxia doctrinal y de moralidad pura, la impronta subjetiva de la vivencia religiosa no es mero efecto del proceso de secularización, según Bellah, más bien se trata de «la progresiva aceptación de que cada individuo debe inda gar sus propias soluciones últimas y que la mayoría de las iglesias pueden 
suministrarle unas circunstancias favorables para llevar a efecto su resolución, sin imponerle un marco prefabricado de respuestas» ${ }^{46}$. Precisamente por el carácter contingente de toda elección, el reverso de esta forma de entender la experiencia religiosa es que las posi bilidades de distorsión patológica en la vida moderna son enormes, precisamente por la falta de institucionalización religiosa y, por extensión, social y de las estructuras de personalidad.

3. Como complemento a la pluralización de universos simbólicos en el marco de la secularidad y a la privatización de la vivencia religiosa, tiene lugar una novedosa reubicación de lo religioso en la modernidad. En efecto, al mismo tiempo que los monopolios religiosos ya no pueden contar con la fidelidad de sus feligreses, la tradición religiosa, antaño impuesta de forma autoritaria, ahora es un producto que depende del marketing. $\mathrm{H}$ a de ser expuesta a la venta junto con el resto de la oferta (economía, política, arte, etc.), con una clientela que ya no está obligada a comprar. Sus productos compiten en igualdad de condiciones junto con otros muchos. Ya no se imponen como los únicos. La situación pluralista es, más que nada, «una situación de mercado. En ella las instituciones religosas se vuelven organizaciones de venta y las tradiciones religosas, artículos de consumo. Por lo menos gran parte de la actividad religosa en semejante situación resulta dominada por la lógica de la economía de mercado» $\$ 7$.

H asta aquí la novedosa situación cosmovisional y estructural en la que se ubica la experiencia religiosa de la sociedad moderna. Conviene ahora incidir en sus formas específicas.

En un detallado y brillante estudio de José $\mathrm{M}$ aría $\mathrm{M}$ ardones sobre las formas actuales de la religión 48 , se anuncia que el retroceso de la religión institucional quiere decir que «la trascendencia se comienza a manifestar mucho más presente en la vida social cotidiana. La religiosidad se configura desde, en, la toma de consciencia de problemas, vivencias, etc. que transitan lo cotidiano, desde la amenaza ecológica, a la sexualidad, la experiencia deportiva, los viajes. El punto de partida y de encuentro de la experiencia de lo trascendente se achica y banaliza, pero se expande por la sociedad. Entramos en lo que un T. Luckmann ha denominado las "pequeñas trascendencias" y "medianas

46. Bellah, R. (1991). Beyond Belief. N ueva York, p. 44

47. Berger, P. (1991). Para una teoría sociológica de la religión. Barcelona, p. 198

48. Para comprender las nuevas formas de la religión, Estella (N avarra), 1994. Se trata de un trabajo muy válido porque, lejos de quedarse en la mera descripción de las formas religiosas pre valecientes, se adentra en lo más específico del discurso religioso, en su fondo sincrónico donde descansan las huellas arquetípicas de las «grandes trascendencias» (Buda, Yahvé, Jesucristo, etc.) dadas en la historia. Precisamente esta apuesta del autor permite desvelar el inextinguible potencial de evocación y resonancias semánticas de las «grandes trascendencias» sobre las que se constata la capacidad creadora de lo sagrado. 
trascendencias" y el alejamiento de la "gran trascendencia" »49. D e esta suerte, el encuentro con lo sagrado puede tener lugar, ya no exclusivamente en una iglesia o mezquita y en compañía de las grandes imágenes (Yahvé, Jesucristo, etc.), sino también en un acontecimiento musical, deportivo, político, etc.50, donde el individuo, bajo una atmósfera colectiva de máxima intensidad psíquica, vivencia y experimenta directamente lo sagrado. D e ahí que la forma religiosa predominante en nuestros días sea (según expresión empleada por J. M. M ardones) la de una religiosidad profana.

La sociedad moderna, por tanto, reubica a la religión en una posición no privilegiada y de partida iguala su «oferta simbólica» a la del resto de sistemas sociales y a sus simbólicas concomitantes. Su expresión cúltica y ritual se vive intramuros, en un espacio circunscrito, delimitado visiblemente por las paredes de los recintos sagrados, de las casas particulares y, en menor medida, en ciertos momentos del mundo escolar. Con este proceso de reclusión de la religión de la vida pública en las sociedades modernas se sustancia lo que Thomas Luckmann denomina privatización de la religión.

En todo caso, este proceso de cambio que ha tenido lugar en la experiencia religiosa de la modernidad no supone una pérdida de importancia y de influencia de su visión del mundo sobre el conjunto de la vida social. Si bien es verdad que con la separación entre lo eclesiástico y lo político la religión ha perdido notoriedad a la hora de dejarse notar su influjo legitimador sobre cierto gobierno político, tanto en sus aciertos como en sus errores, precisamente por eso se ha alejado de cualquier peligro de instrumentalización. D e este modo, se ve libre de cualquier compromiso político, lo cual le permite desenterrar su potencial crítico y de defensa del hombre. En palabras de J.M . M ardones, «a modernidad secularizada puede ser así la gran ocasión para que la religión muestre su lado crítico, desinteresado y militante, en pro del hombre» 51 .

D entro de lo que aquí se denomina religiosidad profana conviene acentuar eso que en nuestros días apunta en lo religioso hacia una nueva actitud espiritual que, frente a la radicalidad del pensamiento instrumental y devastador del espíritu positivista y frente al carácter dogmático e institucional de las formas religiosas predominantes hasta nuestros días, opta por buscar la profundidad de la vida y la vivencia del misterio a instancias del carácter privado de lo religioso. En este sentido, su emergencia responde a una intención contramodernizadora que recuerda la destrucción de la pureza de la naturaleza y, por ende, la del hombre por parte del pensamiento positivista. Sobre este particular, es frecuente en nuestras sociedades la existencia de formas religiosas en las que se da una suerte de sincretismo en el que tienen cabida, además del ideario cristiano aún incólume y de referencias cósmicas, herméticas, psicológicas y humanistas, diferentes elementos procedentes de los nuevos movimientos religiosos de matriz fundamentalista (testigos de Jehová, mormones, etc.), orientalista 
( $\mathrm{H}$ are K rishna, meditación trascendental, etc.) y esotérico-holista (nueva Psicología de carácter transpersonal y mística, esoterismo, etc.), todo ello en un proceso a cuyo través 0 riente y 0 ccidente parecen acercarse bajo la forma de un ecumenismo integrador. A esto refiere J. M . M ardones cuando habla del surgimiento de una «nueva espiritualidad» que expresa una actitud de ligazón y de armonía del hombre actual con lo sagrado que late en la naturaleza, con la divinidad inmanente que fluye por entre todo lo que es vida, en definitiva, un ansia «por conjugar lo personal y privado con lo ecológico y lo cósmico, lo libre y sin trabas con la experiencia profunda natural de lo divino en el fondo de todo» 52 .

Esta nueva actitud espiritual y religiosa de la sociedad actual puede concretarse en cinco rasgos:

1. Relación amistosa con la ciencia, si bien no con la derivación positivista de ésta. Proclama un nuevo paradigma científico, en concreto, un nuevo paradigma holográfico más afín al flujo infinito de energía desde el cual se constituye el orden material en sus tres dimensiones de espacio, tiempo y materia. Se trata de una visión científica que, más que auscultar los hechos tal y como son, profundiza en los hilos energéticos y latentes que comunican a todos los fenómenos que tienen lugar en la naturaleza. Esta visión holis ta de la realidad observa «el universo como un todo viviente espiritual; un todo que es uno y que está presente en todas partes,s3.

2. Proporciona formas y técnicas para provocar en el individuo la búsqueda de la unidad inmanente, del uno originario, de la revelación frente al pensamiento objetivante y dicotómico de la racionalidad occidental. El objetivo de las técnicas de meditación trascendental, yoga, zen, control mental, etc. no es otro que el de vivenciar lo místico, el s'́-mismo, donde el yo se diluye en lo universal.

3. Se privilegian metodologías psicológicas como la psicología transpersonal, la psicol ogía profunda de C.G. Jung, la psicología humanista de A. M aslow, en las que priman las ansias de introspección, de autoconocimiento personal. Se trata del reencuentro del individuo con ámbitos de su psique mayormente desconocidos, con lo originario, con el silencio iluminador, todo lo cual facilita su regeneración y crecimiento personal.

4. La comunicación con lo eterno latente en toda experiencia humana abre en esta nueva actitud espiritual un lugar para el esoterismo, en concreto, para el contacto con personas muy distantes en el tiempo y en el espacio. En esta idea mística se apoya la forma moderna del espiritismo clásico donde el medium hace las veces de canal por el que se transmiten las revelaciones de los espíritus superiores o se entra en contacto con personas difuntas, se desvelan las vidas ya anteriormente vividas, etc. 
5. Por último, se apoya un reencantamiento de la naturaleza frente a la visión desencantada que propuso el positivismo científico-técnico. Esta actitud de acercamiento hacia la naturaleza incluye a todos los seres vivos y al hombre. Éste, incrustado en su ciclo vital como elemento portador de inteligencia, consciencia su profunda integración y armonía con el ser profundo de la naturaleza, con su inextinguible potencial creador y, por ende, redescubre lo divino en una inmanencia de la que el hombre (y todo ser vivo) participa hasta en sus acciones cotidianas más banales (lo cual desemboca en una sacramentalización de lo sagrado).

En este sentido, la religiosidad profana por la que opta la sociedad moderna no se ajusta al formato institucional del tipo «lglesia» 0 «secta», más bien responde a lo que se ha dado en llamar comunidades emoci onales que, desprovistas de textos sagrados, organismos y dogma y establecidas sobre contornos institucionales difusos y afiliación fluida y cambiante según las necesidades individuales, giran en torno a un «líder» que tampoco hace las veces de organizador y controlador religioso. Y ello porque, como ya se ha anunciado anteriormente, en este contexto de «nueva espiritualidad» la dimensión religiosa recae sobre el individuo y su desarrollo personal, en concreto, la adquisición de un estado anímico grato apto para el encuentro con la trascendencia inmanente, con el fondo sagrado o ś-mi smo que late en su existencia y del que participa toda otra realidad (no humana).

En todo caso, conviene recordar algo que ya se ha dicho antes. Si bien es verdad que la sensibilidad religiosa de la modernidad ha redescubierto horizontes de la existencia y de la vida olvidados por el pensamiento racional y científico imperante hasta nuestros días, el cariz un tanto esotérico y abierto al experimentalismo de la emocionalidad individual puede suponer caer en el otro extremo, en el de la trivialización de lo sagrado y en el de la pérdida de ciertos esquemas críticos a cuyo través lo emocional puede quedarse fijado en las mediaciones rituales con el peligro de fomentar un nuevo dogmatismo54.

Una ejemplificación ritual que se adecúa a la religi osidad profana imperante en la modernidad y que hace de lo político marco de experimentación de lo sagrado lo constituye lo que Robert Bellah (entre otros) ha denominado la religi ón ci vil americana, siempre sobre la base de que, como pensaba D urkheim, «en condiciones de modernidad, toda religión es, en última instancia, civil, por lo menos en la medida en que plasma sus representaciones, fines morales, mitos y símbolos en entes socialmente creados»\$5. Este sociólogo americano considera que desde los tiempos fundacionales de la república americana se puede constatar la existencia de un «entramado de creencias, símbolos y ritos»,56 referido a las cosas sagradas institucionalizadas en la colectividad. En el des-

54. M ARD O NeS, J.M . (1955). Análisis de la sociedad y fe cristiana. M adrid, p. 225.

55. GINER, S. (1994). «La religión civil». En DiAz-SALAZAR, R.; VelASCO, Fernando (eds.). Formas modernas de religión. M adrid, p. 14.

56. Bellah, R. (1991). O p. cit., p. 171. 
pliegue de actos de gran valor público como mensajes navideños, días de duelo nacional, celebraciones de la C onstitución o aniversarios históricos de la I glesía, el Día de la Acción de Gracias, el día ante la Tumba del Soldado D esconocido, los discursos de los políticos, se manifiesta una suerte de «sacralización de ciertos rasgos de la vida comunitaria» 57 encaminada a reforzar la identidad y el orden en una colectividad socialmente heterogénea, confiriendo a esta identidad y a este orden «trascendencia mediante la dotación de carga numinosa a sus símbolos mundanos o sobrenaturales, así como de carga épica a su historia»58.

$M$ ayormente referida a una identidad colectiva nacional ${ }^{59}$, Ia religión civil y todos sus ritos, símbolos y referencias históricas no son ajenos a la moderna separación I glesia-Estado, lo cual garantiza la libertad de creencia religiosa y de asociación y, al mismo tiempo, confina a la esfera religiosa en los límites de lo privado. En efecto, cuando en muchos de los discursos de los diferentes políticos americanos (A. Lincoln; J. F. Kennedy, etc.) se menta la palabra «D ios» («n God we Trust», «Under God», etc.) no se hace en favor (o en detrimento) de credos concretos. Las cuestiones de creencia religiosa personal, de culto y de asociación pertenecen al ámbito privado, pero existen, al mismo tiempo, ciertos símbolos comunes (fechas, acontecimientos, imágenes, personalidades, etc.) de orientación religiosa que la gran mayoría de los americanos comparten 60 .

Estos ritos laicos de la religión civil, más relacionados con el orden y el derecho que con la salvación y el amor61, no son claramente cristianos aunque se derivan selectivamente del cristianismo. La misma religión civil aparece como religión common sense y, por tanto, se libera de los contenidos de la dogmática religiosa. Sus mensajes y símbolos facilitan el logro de «aquel mínimo que se supone que es lo máximo que está en condiciones de obtener consenso social (generalizado)»62. Sus ritos sacralizadores de lo colectivo americano son más bien entendidos como públicamente consensuales y como relevantes para el bien común.

En definitiva, en estas manifestaciones rituales de la nación americana se constata y se salva el vínculo constitutivo entre individuo y sociedad por cuanto se estructuran sobre unas mitologías con las que los ritmos, instituciones y valores de la sociedad adquieren legitimidad. Sus permanentes alusiones simbólicas al origen y al destino (al pasado y al futuro) de la nación americana ratifican la coherencia interna de la sociedad y logran de ésta la lealtad pública. 